World Health Organization's plan to eradicate poliovirus from the planet will necessitate. Given some of the ongoing logistical problems with this noble effort, researchers may yet have time to uncover some of the long-standing mysteries of viral pathogenesis presented by the unique tropism and disease characteristics of poliovirus infections.

Address correspondence to: Bert L. Semler, Department of Microbiology and Molecular Genetics, College of Medicine, Medical Sciences B240, University of California, Irvine, California 92697, USA. Phone: (949) 824-7573; Fax: (949) 824-2694; E-mail: blsemler@uci.edu.

1. Kitamura, N., et al. 1981. Primary structure, gene organization and polypeptide expression of poliovirus RNA. Nature. 291:547-553.

2. Racaniello, V.R., and Baltimore, D. 1981. Molecular cloning of poliovirus cDNA and determination of the complete nucleotide sequence of the viral genome. Proc. Natl. Acad. Sci. U. S. A. 78:4887-4891.

3. Stanway, G., et al. 1983. The nucleotide sequence of poliovirus type 3 leon $12 \mathrm{a} 1 \mathrm{~b}$ : comparison with poliovirus type 1. Nucleic Acids Res. 11:5629-5643.

4. Toyoda, H., et al. 1984. Complete nucleotide sequences of all three poliovirus serotype genomes. Implication for genetic relationship, gene function and antigenic determinants. J. Mol. Biol. 174:561-585.

5. Nomoto, A., et al. 1982. Complete nucleotidesequence of the attenuated poliovirus Sabin 1 strain genome. Proc. Natl. Acad. Sci. U. S. A. 79:5793-5797.

6. Stanway, G., et al. 1984. Comparison of the complete nucleotide sequences of the genomes of the neurovirulent poliovirus $\mathrm{P} 3 / \mathrm{Leon} / 37$ and its attenuated Sabin vaccine derivative P3/Leon 12a1b. Proc. Natl. Acad. Sci. U. S. A. 81:1539-1543.

7. Wimmer, E., Hellen, C.U., and Cao, X. 1993. Genetics of poliovirus. Annu. Rev. Genet. 27:353-436.

8. Evans, D.M.A., et al. 1985. Increased neurovirulence associated with a single nucleotide change in a noncoding region of the Sabin type 3 poliovaccine genome. Nature. 314:548-550.

9. Gromeier, M., and Nomoto, A. 2002. Determinants of poliovirus pathogenesis. In Molecular biology of picornaviruses. B.L. Semler and E. Wimmer, editors. ASM Press. Washington, DC, USA. 367-379.

10. Minor, P.D., and Almond, J. 2002. Poliovirus vaccines: molecular biology and immune response. In Molecular biology of picornaviruses. B.L. Semler and E. Wimmer, editors. ASM Press. Washington, DC, USA. 381-390.

11. Hellen, C.U., and Sarnow, P. 2001. Internal ribosome entry sites in eukaryotic mRNA molecules. Genes Dev. 15:1593-1612.

12. Svitkin, Y.V., Maslova, S.V., and Agol, V.I. 1985. The genomes of attenuated and virulent poliovirus strains differ in their in vitro translation efficiencies. Virology. 147:243-252.

13. Svitkin, Y.V., Cammack, N., Minor, P.D., and Almond, J.W. 1990. Translation deficiency of the Sabin type 3 poliovirus genome: association with an attenuating mutation C472 $\rightarrow$ U. Virology. 175:103-109.

14. La Monica, N., and Racaniello, V.R. 1989. Differences in replication of attenuated and neurovirulent polioviruses in human neuroblastoma cell line SH-SY5Y. J. Virol. 63:2357-2360.

15. Haller, A.A., Stewart, S.R., and Semler, B.L. 1996 Attenuation stem-loop lesions in the 5 ' noncoding region of poliovirus RNA: neuronal cell-specific translation defects. J. Virol. 70:1467-1474.

16. Kauder, S.E., and Racaniello, V.R. 2004. Poliovirus tropism and attenuation are determined after internal ribosome entry. J. Clin. Invest. 113:1743-1753. doi:101172/JCI200421323.
17. Ren, R.B., Costantini, F., Gorgacz, E.J., Lee, J.J., and Racaniello, V.R. 1990. Transgenic mice expressing a human poliovirus receptor: a new model for poliomyelitis. Cell. 63:353-362.

18. Koike, S., et al. 1991. Transgenic mice susceptible to poliovirus. Proc. Natl. Acad. Sci. U. S. A. 88:951-955.

19. Ren, R., and Racaniello, V.R. 1992. Human poliovirus receptor gene expression and poliovirus tissue tropism in transgenic mice. J. Virol. 66:296-304.

20. Holland, J.J. 1961. Receptor affinities as major determinants of enterovirus tissue tropisms in humans. Virology. 15:312-326.

21. Gromeier, M., Alexander, L., and Wimmer, E. 1996. Internal ribosomal entry site substitution eliminates neurovirulence in intergeneric poliovirus recombinants. Proc. Natl. Acad. Sci. U. S. A. 93:2370-2375.

22. Gromeier, M., Bossert, B., Arita, M., Nomoto, A., and Wimmer, E. 1999. Dual stem loops within the poliovirus internal ribosomal entry site control neurovirulence. J. Virol. 73:958-964.

23. Yanagiya, A., et al. 2003. Tissue-specific replicating capacity of a chimeric poliovirus that carries the internal ribosome entry site of hepatitis $\mathrm{C}$ virus in a new mouse model transgenic for the human poliovirus receptor. J. Virol. 77:10479-10487.

24. Borman, A.M., Deliat, F.G., and Kean, K.M. 1994. Sequences within the poliovirus internal ribosome entry segment control viral RNA synthesis. $E M B O$ J. 13:3149-3157.

25. Shiroki, K., et al. 1995. A new cis-acting element for RNA replication within the $5^{\prime}$ noncoding region of poliovirus type 1 RNA. J. Virol. 69:6825-6832.

26. Crotty, S., Hix, L., Sigal, L.J., and Andino, R. 2002. Poliovirus pathogenesis in a new poliovirus receptor transgenic mouse model: age-dependent paralysis and a mucosal route of infection. J. Gen. Virol. 83:1707-1720

27. Nagata, N., et al. 2004. A poliomyelitis model through mucosal infection in transgenic mice bearing human poliovirus receptor, TgPVR21. Virology. 321:87-100.

\title{
Is transplantation tolerable?
}

\author{
Terry B. Strom
}

Division of Immunology and Transplant Research Center, Beth Israel Deaconess Medical Center, Harvard Medical School, Boston, Massachusetts, USA.

\begin{abstract}
To test the hypothesis that chronic stimulation of $\mathrm{T}$ cells with a weak agonistic antigen will generate regulatory $T$ cells and immune tolerance, a study reported in this issue (see the related article beginning on page 1754) employed the redesign of a minor histocompatibility antigen. Using knowledge of residues at which the antigen contacts the $T$ cell receptor, a weak agonist was produced. Pretreatment with this altered antigen produced transplant tolerance, generation of regulatory $T$ cells, and a loss of many antigen-reactive $T$ cells.
\end{abstract}

In brackish waters once trafficked by oldschool cellular immunologists, precious texts describing the wonders of somewhat

Nonstandard abbreviations used: altered peptide ligand (APL); glucocorticoid-induced TNF receptor (GITR); T cell receptor (TCR).

Conflict of interest: The author has declared that no conflict of interest exists.

Citation for this article:

J. Clin. Invest. 113:1681-1683 (2004).

doi:10.1172/JCI200422153. ill-defined suppressor lymphocytes (1) were jettisoned. Later works, also discarded, described lymphocytes able to protect rather than destroy foreign tissues in adult hosts rendered tolerant to organ transplants $(2-4)$. CD4 ${ }^{+}$, IL-2 receptor-positive $\left(\mathrm{CD} 25^{+}\right) \mathrm{T}$ cells capable of countering the graft-destroying properties of alloaggressive $\mathrm{T}$ cells were identified by Hall and his colleagues in rodent transplant models (2). Nonetheless, following the fashion of the time, many of us cleansed our grants and manuscripts of any mention of suppressor $\mathrm{T}$ cells. Following a revival of interest in suppressor, or regulatory, $\mathrm{T}$ cells, Chen et al. in this issue of the JCI (5) have now redesigned a minor histocompatibility antigen to test the hypothesis that chronic stimulation of $\mathrm{T}$ cells with a weak agonistic antigen will generate regulatory $T$ cells and produce immune tolerance.

In the 1990s, an era in which the phrase "suppressor T cells" was uttered only in hushed tones, a series of brilliant experiments by Waldmann $(6,7)$ and his colleagues identified a crucial graft-protecting $\mathrm{T}$ cell-dependent network in hosts rendered tolerant to transplants by means other than creation of total and enduring deletion of antidonor clones. Tolerant host 
A

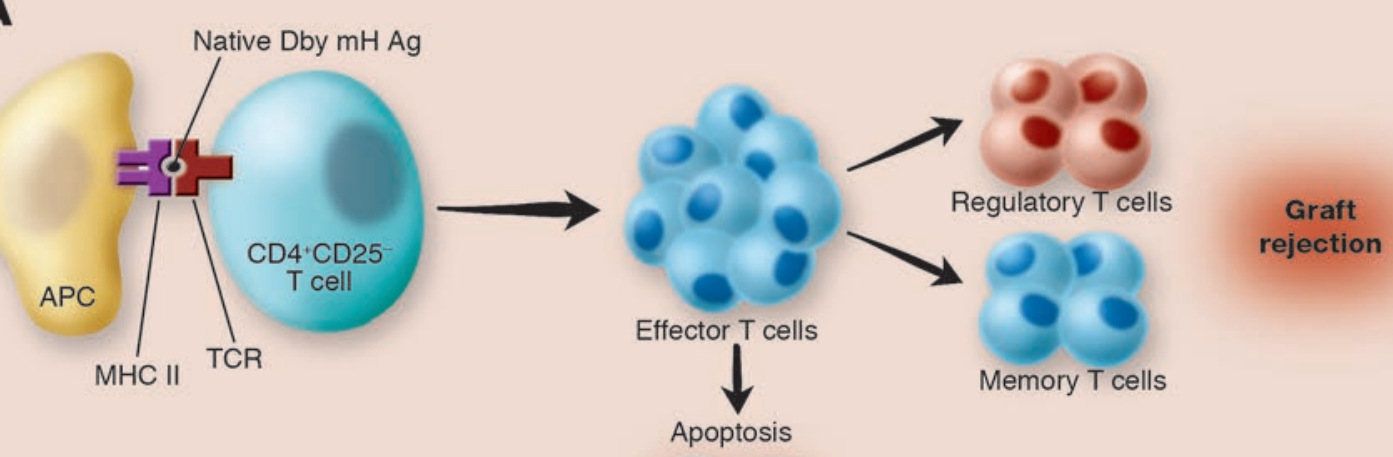

B
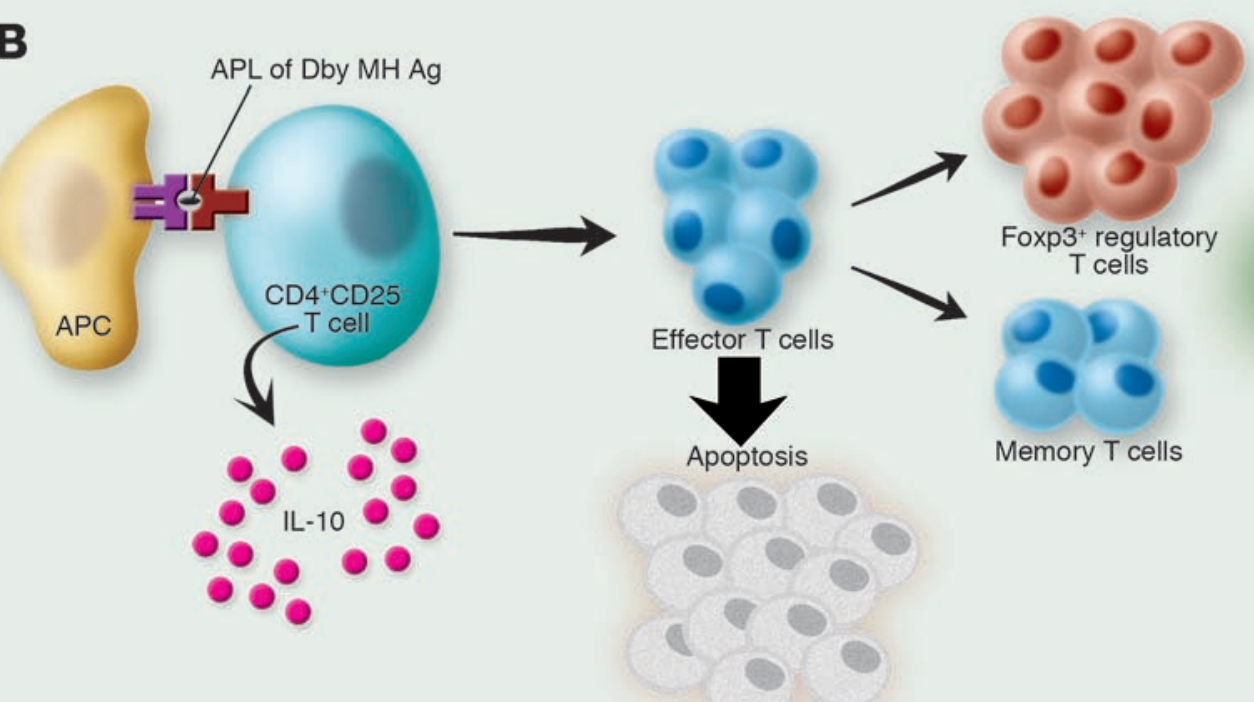

Graft

tolerance

Figure 1

As compared with antigenic stimulation $(\mathbf{A})$, stimulation of female transgenic mice with an APL of the Dby minor histocompatibility (mH) antigen, which delivers incomplete signals to naive T cells, (a) promotes the production of Foxp3 $3^{+}$regulatory T cells, (b) limits the development of effector $\mathrm{T}$ cells, and (c) magnifies the apoptotic loss of activated T cells (B), resulting in tolerance to male skin grafts. Ag, antigen.

antidonor $\mathrm{CD}^{+} \mathrm{T}$ cells can recruit nontolerant syngeneic $\mathrm{T}$ cells to protect the donor graft. The detailed cellular basis of this $\mathrm{CD}^{+} \mathrm{T}$ cell-dependent network remains somewhat elusive, although rapid progress is being made.

With the discovery that antigen-stimulated $\mathrm{CD}^{+} \mathrm{T}$ cells can polarize into either a Th1 or a Th 2 response, it became clear that graft rejection was usually the result of a Th1-type immune response. In contrast, many donor-reactive CD $4^{+} \mathrm{T}$ cells in tolerant hosts manifest a Th2-type program $(8,9)$. The possibility that Th2-type T cells served as the cellular basis of peripheral transplant tolerance was a welcome relief to many, because, unlike the shadowy suppressor cells of old, IL-4- and IL-10-pro- ducing Th2 cells have a defined molecular program. Unlike the situation that pertains to MHC-matched allografts, Th1-toTh2 immune deviation does not provide a comprehensive basis for transplant tolerance in MHC-mismatched models (10). Vigorous rejection of MHC-mismatched allografts can be mounted despite marked Th1-to-Th2 immune deviation. Perhaps, Th1-to-Th2 immune deviation is necessary but not sufficient to produce tolerance in many situations.

\section{Recovering the legacy of suppressor lymphocytes}

A revival in interest in suppressor (also known as regulatory) $\mathrm{T}$ cells began with the discovery that $\mathrm{CD} 4^{+} \mathrm{CD} 25^{+} \mathrm{T}$ cells pres- ent in naive hosts can counteract autoreactive, Th1-dependent cytopathic programs (reviewed in ref. 11). Similar observations were soon made in mouse transplant models (reviewed in ref. 12). In the naive host, $\mathrm{CD} 4{ }^{+} \mathrm{CD} 25^{+}$regulatory $\mathrm{T}$ cells express cell surface glucocorticoid-induced TNF receptor (GITR) molecules (11-13). The $\mathrm{CD}^{+} \mathrm{CD} 25^{+} \mathrm{GITR}^{+}$phenotype does not clearly define the regulatory $\mathrm{T}$ cell population, since activated, nonregulatory $\mathrm{T}$ cells can express CD25 and GITR. Expression of Foxp3 provides a more precise marker for regulatory $\mathrm{T}$ cell development and function $(14,15)$. Moreover, Foxp3 serves as a master switch to trigger the suppressor function of regulatory $\mathrm{T}$ cells. Insofar as TGF- $\beta$, a cytokine with known immunosuppressive 
effects, can trigger expansion of Foxp $3^{+}$regulatory $\mathrm{T}$ cells (16), a link between immunosuppressive cytokines and $\mathrm{T}$ cell-based immunoregulation has been uncovered. While $\mathrm{CD}^{+} \mathrm{CD} 25^{+} \mathrm{Foxp}^{+} \mathrm{T}$ cells have been clearly identified as regulatory $\mathrm{T}$ cells, there is no evidence that all immunoregulatory $\mathrm{T}$ cells express this phenotype. IL-10-producing $\mathrm{CD}^{+} \operatorname{Tr} 1$ cells and other $\mathrm{T}$ cell subtypes have been implicated as serving an immunoregulatory function in several immune system models (17).

\section{Manufacturing transplant tolerance}

The belief that the outcome of allograft response - rejection or tolerance - following the withdrawal of immunosuppressive therapy is determined by the balance of alloaggressive to graft-protecting $\mathrm{T}$ cells is now emerging. In most situations, tolerance is not accompanied by permanent and complete deletion of alloaggressive donorreactive $T$ cells, and regulatory networks are required. Regimens that temporarily deplete cytopathic $\mathrm{T}$ cells aid tolerance induction (18-20) but do not replace the requirement for regulatory $\mathrm{T}$ cells $(21)$.

It is in the context of favorably altering the balance of cytopathic to protective $\mathrm{T}$ cells that the importance of the work of Chen et al. (5), appearing in this issue of the JCI, must be considered. Can regulatory $\mathrm{T}$ cells be manufactured to aid tolerance induction? Yes, they can. How? Persistent and suboptimal stimulation of the $\mathrm{T}$ cell receptor (TCR) complex has been linked to the recruitment of $\mathrm{T}$ cells into the pool of regulatory $\mathrm{T}$ cells (22). To probe the implications of this hypothesis, Chen et al. rationally designed an altered peptide ligand (APL) for the antigenic epitope of the Dby peptide. The Dby gene, located on the Y chromosome, stimulates rejection of male skin grafts by same-strain female recipients. As anticipated, the targeted alterations in the TCR-binding epitope compromise the binding affinity with the TCR (Figure 1). Moreover, challenge of Dbyreactive TCR transgenic T cells with the APL generated "incomplete" $\mathrm{T}$ cell activation signals, as deduced by several assays. Interestingly, stimulation of the TCR with the APL, but not with the native epitope, triggered copious secretion of IL-10 by CD $4^{+} \mathrm{CD} 25^{-} \mathrm{T}$ cells. The propensity of APL-stimulated TCR transgenic T cells to robustly express IL-10 is an attribute shared with naturally occurring Tr1-type and other regulatory cells (17). Pretreatment of female mice with the APL, but not pretreatment with saline or the native Dby epitope, induced a state of prolonged tolerance to male skin transplants even when coadministered with saturating doses of a blocking anti-IL-10 receptor $\mathrm{mAb}$. IL-10 is a surrogate marker for the effector molecules driving tolerance in this model. T cells in APL-treated mice counteract the ability of untreated $\mathrm{T}$ cells to reject donor, male-type skin transplants.

In keeping with other models of peripheral transplant tolerance, robust Foxp3 expression in APL-treated tolerant, but not in control, transplanted tissue (skin) or spleen is manifest (5). Nonetheless, in other models of peripheral tolerance in which Foxp $3^{+} \mathrm{T}$ cells have been found within the graft and peripheral lymphoid tissues, thymic Foxp $3^{+}$ $\mathrm{T}$ cells are also present. In this APL-driven model of transplant tolerance, Foxp $3^{+} \mathrm{T}$ cells cannot be identified within the host thymus. This observation unequivocally proves that Foxp3-expressing regulatory $\mathrm{T}$ cells need not be derived only from $\mathrm{CD} 4^{+} \mathrm{CD} 25^{+} \mathrm{Foxp} 3^{+}$ thymic $T$ cells, as they can be recruited from peripheral Foxp3-null T cells not predestined to become Foxp $3^{+}$regulatory T cells. Finally, stimulation with a weakly agonistic APL serves not only to generate regulatory $\mathrm{T}$ cells; it also produced gross depletion of peripheral, but not thymic, antigen-reactive $T$ cells (5). In keeping with the hypothesis that tolerance is efficiently promoted by generation of donor-reactive regulatory $\mathrm{T}$ cells plus partial depletion of donor-reactive aggressive $\mathrm{T}$ cells, APL treatment produced a depletion of splenic, but not thymic, Dby-reactive T cells.

Taken together, this work (5) indicates that chronic stimulation of $\mathrm{T}$ cells with a weak TCR agonist promotes post-thymic differentiation of potent regulatory $\mathrm{T}$ cells and partial but extensive post-thymic depletion of donor-reactive aggressive $\mathrm{T}$ cells. While there has been great emphasis on treatments that curtail the destructive properties of conventional $\mathrm{T}$ cells, the knowledge that $\mathrm{T}$ cells with graft-protective properties can be trained and propagated in vivo provides a new tool for attempting to tilt the allograft response toward tolerance. Insofar as the same treatment destroys antigen-reactive effector T cells, a very favorable alteration in the balance of graft-destroying to graft-protective $\mathrm{T}$ cells becomes manifest.

Address correspondence to: Terry B. Strom, Division of Immunology and the Transplant Research Center, Beth Israel Deaconess Medical Center, 77 Avenue Louis Pasteur, HIM-1 Room 1027, Boston, Massachusetts 02115, USA. Phone: (617) 667-0850; Fax: (617) 6670923; E-mail: tstrom@bidmc.harvard.edu.
1. Gershon, R.K., and Kondo, K. 1970. Cell interactions in the induction of tolerance: the role of thymic lymphocytes. Immunology. 18:723-735.

2. Hall, B., Jelbart, M.E., Gurley, K.E., and Dorsch, S.E. 1990. Specific unresponsiveness in rats with prolonged cardiac allograft survival after treatment with cyclosporine. III. Further characterization of the CD4+ suppressor cell and its mechanisms of action. J. Exp. Med. 171:141-157.

3. Hall, B.M. 1985. Mechanisms maintaining enhancement of allografts. I. Demonstration of a specific suppressor cell. J. Exp. Med. 161:123-133.

4. Hendry, W.S., et al. 1979. Transfer of specific unresponsiveness to organ allografts by thymocytes. Specific unresponsiveness by thymocyte transfer. J. Exp. Med. 149:1042-1055.

5. Chen, T.-C., Waldmann, H., and Fairchild, P.J. 2004. Induction of dominant transplantation tolerance by an altered peptide ligand of the male antigen Dby. J. Clin. Invest. 113:1754-1762. doi:10.1172/ JCI200420569.

6. Waldmann, H. 2002. Reprogramming the immune system. Immunol. Rev. 185:18-32.

7. Qin, S., et al. 1993. "Infectious" transplantation tolerance. Science. 259:974-977.

8. Sayegh, M.H., et al. 1995. CD28-B7 blockade after alloantigenic challenge in vivo inhibits Th1 cytokines but spares Th2. J. Exp. Med. 181:1869-1874.

9. Takeuchi, T., Lowry, R.P., and Konieczny, B. 1992. Heart allografts in murine systems. The differential activation of Th2-like effector cells in peripheral tolerance. Transplantation. 53:1281-1294.

10. Li, X.C., Zand, M.S., Li, Y., Zheng, X.X., and Strom, T.B. 1998. On histocompatibility barriers, Th1 to Th2 immune deviation, and the nature of the allograft responses. J. Immunol. 161:2241-2247.

11. Shevach, E.M. 2000. Regulatory T cells in autoimmunity. Annu. Rev. Immunol. 18:423-449.

12. Wood, K.J., and Sakaguchi, S. 2003. Regulatory T cells in transplantation tolerance. Nat. Rev. Immunol. 3:199-210.

13. Lakkis, F.G., et al. 1997. Blocking the CD28-B7 T cell costimulation pathway induces low term cardiac allograft acceptance in the absence of IL-4. J. Immunol. 158:2443-2448.

14. Hori, S., Nomura, T., and Sakaguchi, S. 2003. Control of regulatory $\mathrm{T}$ cell development by the transcription factor Foxp3. Science. 299:1057-1061.

15. Khattri, R., Cox, T., Yasayko, S.A., and Ramsdell, F. 2003. An essential role for Scurfin in CD4-CD25+ $\mathrm{T}$ regulatory cells. Nat. Immunol. 4:337-342.

16. Peng, Y., Laouar, Y., Li, M.O., Green, E.A., and Flavell, R.A. 2004. TGF-beta regulates in vivo expansion of Foxp3-expressing CD4+CD25+ regulatory $\mathrm{T}$ cells responsible for protection against diabetes. Proc. Natl. Acad. Sci. U. S. A. 101:4572-4577.

17. Groux, H., et al. 1997. A CD4+ T-cell subset inhibits antigen-specific T-cell responses and prevents colitis. Nature. 389:737-741.

18. Dai, Z., Konieczny, B.T., Baddoura, F.K., and Lakkis, F.G. 1998. Impaired alloantigen-mediated $\mathrm{T}$ cell apoptosis and failure to induce long-term allograft survival in IL-2-deficient mice. J. Immunol. 161:1659-1663

19. Li, Y., Li, X.C., Wells, A.D., Turka, L.A., and Strom, T.B. 1999. Blocking both signal 1 and signal 2 of T-cell activation prevents apoptosis of alloreactive $\mathrm{T}$ cells and induction of peripheral allograft tolerance. Nat. Med. 5:1298-1302.

20. Wells, A.D., et al. 1999. Requirement for T cell apoptosis in the induction of peripheral transplantation tolerance. Nat. Med. 5:1303-1307.

21. Zheng, X.X., et al. 2003. Favorably tipping the balance between cytopathic and regulatory $T$ cells to create transplantation tolerance. Immunity. 19:503-514.

22. Sloan-Lancaster, J., and Allen, M. 1996. Altered peptide ligand-induced partial $\mathrm{T}$ cell activation: molecular mechanisms and role in T cell biology. Annu. Rev. Immunol. 14:1-27. 